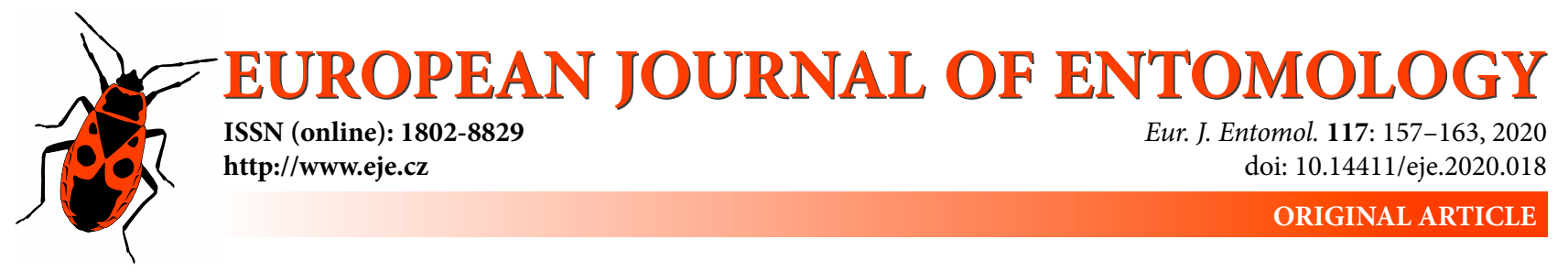

\title{
Tribal affiliation of endemic Macaronesian bush-crickets similar to Tettigonia (Orthoptera: Tettigoniidae) based on their karyology and taxonomy
}

\author{
Elżbieta WARChAŁOWSKA-ŚliWA ${ }^{1}$, Howon RHEE ${ }^{2}$, KLAus-Gerhard HELLER ${ }^{3}$ and Beata GRZYWACZ ${ }^{1}$ \\ ${ }^{1}$ Institute of Systematics and Evolution of Animals, Polish Academy of Sciences, Kraków, Poland; \\ e-mails: warchalowska@isez.pan.krakow.pl; grzywacz@isez.pan.krakow.pl \\ 2 Trier University, Department of Biogeography, Trier, Rheinland-Pfalz, Germany; e-mail: s6horhee@uni-trier.de \\ ${ }^{3}$ Magdeburg, Germany; e-mail: heller.volleth@t-online.de
}

Key words. Orthoptera, Tettigoniidae, Calliphona, Psalmatophanes, Canary Islands, Madeira, chromosomes, systematics

\begin{abstract}
Two endemic genera of large tettigoniids are found in the Canary Islands and Madeira, which are morphologically similar to the genus Tettigonia. In this study, the karyotypes of representatives of the Glyphonotini genera Calliphona and Psalmatophanes are described for the first time. Comparison of their chromosomes with that of members of Tettigoniini genus Tettigonia revealed that all of the species studied have the same karyotype $(2 n=29$ with sex determination system X0 in the male), which differs from the ancestral tettigoniid karyotype by one Robertsonian translocation. These results support not only the morphological and molecular genetic evidence but also the hypothesis of a close relationship between Tettigonia and the endemics Calliphona and Psalmatophanes. Cytogenetic data of Glyphonotini strongly indicate that the taxonomy of thes lineage needs to be re-evaluated in which evidence from multiple sources could help resolve the taxonomic problems.
\end{abstract}

\section{INTRODUCTION}

The Macaronesian region, situated in the North Atlantic Ocean west of North Africa and South West Europe, includes four large archipelagos. Canary Islands and Madeira are closest to the African mainland, while the Azores are further away in the ocean and Cape Verde is much further south than the other three archipelagos. All islands are of volcanic origin and have never been in contact with the mainland (true 'oceanic islands'). Therefore, all species living there must be descendants of immigrants and are expected to have their closest relatives in nearby mainland, except for newly introduced species.

Sometime after their arrival the immigrants may evolve into new species. Among the orthopteran species in the Macaronesian region, this change does not seem to have happened very often. Cape Verde has one endemic species (among 34 species occurring there; Harz, 1982; Mestre \& Chiffaud, 1997; Buzzetti et al., 2005), the Azores one (among 14 species; De Sousa \& Borges, 2005) and Madeira four (among 24 species; Lange, 1990). Only in the Canary Islands are a high percentage (about 45\%) of all Orthoptera endemic (37 of 81 species; Bland et al., 1996, Bland, 2001; Hochkirch, pers. comm.). The number of endemic genera is of course smaller, with one in Madeira (Psalmatophanes Chopard, 1938) and seven (Acrostira
Enderlein, 1929; Ariagona Krauss, 1892; Arminda Krauss, 1892; Calliphona Krauss, 1892; Canariola Uvarov, 1940; Evergoderes Bolivar, 1936; Purpuraria Enderlein, 1929) in the Canary Islands, being only about one quarter to one fifth of the number of endemic species. These groups have diverged so much from their ancestors that their relationships are sometimes obscure or doubtful. This is the case for the tribal affiliation the tettigoniid genera Calliphona (Fig. 1a) and Psalmatophanes Chopard, 1938 (Fig. 1b), which is uncertain. Although both genera at present do not belong to the same tribe as Tettigonia Linneaus, 1758, they were considered as similar or closely related to this genus at the time of their description [(Krauss, 1892; Chopard, 1938; Bolívar, 1940 (revised 1991)] and later (e.g. Holzapfel \& Cantrall, 1972; Pfau \& Pfau, 2002). However, Rentz $\&$ Colless (1990) conclude after an extensive morphological review of the whole subfamily that they might belong to the tribe Glyphonotini, with relatives only in Central Asia, Australia and North West America, which is their currently accepted classification (Cigliano et al., 2020). Rentz \& Colless (1990) were surprised by their conclusion because it was difficult to explain in terms of biogeography. Later Arnedo et al. (2008) confirmed the close relationship of Psalmatophanes to Tettigonia based on a detailed molecular phylogenetic study, but did not change the classification 

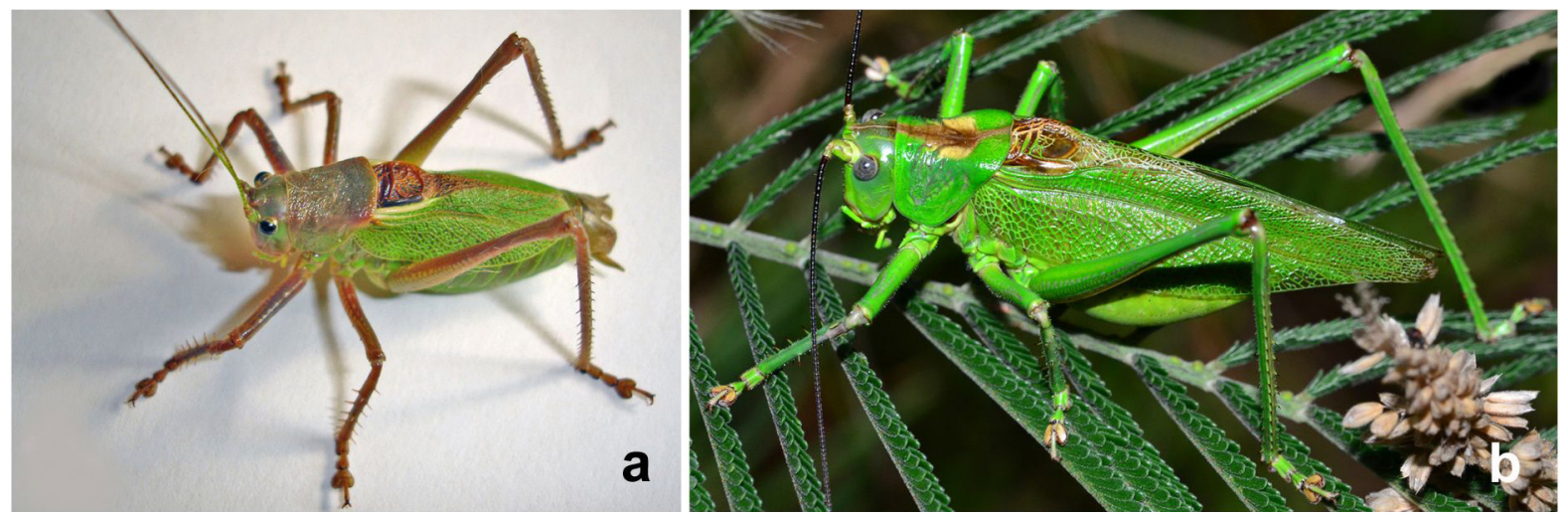

Fig. 1. Habitus of Calliphona koenigi (a) and Psalmatophanes barettoi (b) for comparison with Tettigonia see e.g. Fig. 5 in Grzywacz et al. (2017b).

of Rentz \& Colless (1990). Since we had the opportunity to collect specimens of both genera and analyse their chromosomes, we used these new characters in a taxonomic reevaluation of the situation, which included a comparison of several species of Tettigonia.

Comparative cytogenetic studies on more than 130 species from the subfamily Tettigoniinae (sensu Cigliano et al., 2020) reveal that diploid chromosome number (2n) varies from 15 to 33 in most cases with an X0 sex determination system. Most of the Old World species have 31 acrocentric chromosomes, but the few Australian and New World species diverge from the standard chromosome number with one or more bi-armed autosomes and often a metacentric X chromosome (e.g. reviewed Warchałowska-Śliwa, 1998). Until now, standard staining techniques (alcoholcarmine or Giemsa) have been used in studies of the tribe Glyphonotini (Bugrov, 1990; Ueshima \& Rentz, 1990) and $\mathrm{C}$-banding and the nucleolar organizer region (NOR) staining for those of the tribe Tettigoniini (Warchałowska-Śliwa \& Bugrov, 1997; Warchałowska-Śliwa \& MaryańskaNadachowska, 1995a, b; Warchałowska et al., 2002).

In this study, nine taxa from two Tettigoniinae tribes, the Glyphonotini and Tettigoniini, were analysed using different cytogenetic techniques, such as C-banding, sil- ver impregnation (Ag-NOR), fluorochrome staining and fluorescence in situ hybridization (FISH) using $18 \mathrm{~S}$ rDNA and telomeric (TTAGG) ${ }_{n}$ as probes. We aimed to describe the karyotypes and identify cytogenetic patterns as the first step towards a better understanding of the relationships at different taxonomic levels.

\section{MATERIALS AND METHODS}

This study included two species belonging to the tribe Glyphonotini: Psalmatophanes barettoi Chopard, 1938 (2 males) and Calliphona koenigi Krauss, 1892 (2 males) and seven taxa of Tettigonia (Tettigoniini): T. armeniaca complex (two males), T. balcanica Chobanov \& Lemonnier-Darcemont, 2014 (one male), T. cantans (Fuessly, 1775) (one male), T. caudata (Charpentier, 1845) (one male), T. viridissima (Linnaeus, 1758) (four males), T. cf. viridissima (one male) and the T. vaucheriana complex (two males) (Table 1).

Gonads were incubated in a hypotonic solution $(0.9 \%$ sodium citrate), then fixed in Carnoy's solution (ethanol and acetic acid, $3: 1$ ) and squashed in a drop of $45 \%$ acetic acid. The coverslip was removed using the dry ice procedure. Slides were dehydrated and then air dried. C-banding was done according to Sumner (1972). Constitutive heterochromatin was analysed qualitatively by $\mathrm{CMA}_{3}$ (chromomycin $\mathrm{A}_{3}$ ) and DAPI (4,6-diamidino-2-phenylindole) staining according to Schweizer (1976). Silver nitrate staining of active nucleolus organizing regions (NORs) was

Table 1. Localities at which the species analysed in this study were collected.

\begin{tabular}{|c|c|c|}
\hline Species & Collection site and voucher ID & $\begin{array}{l}\text { Geographical } \\
\text { coordinates }\end{array}$ \\
\hline Psalmatophanes barretoi Chopard, 1938 & $\begin{array}{l}\text { Portugal: Madeira; (1) CHX375, } \\
(2) \mathrm{CHX376}\end{array}$ & $\begin{array}{l}32.783^{\circ} \mathrm{N}, 16.883^{\circ} \mathrm{W} \\
32.817^{\circ} \mathrm{N}, 16.917^{\circ} \mathrm{W}\end{array}$ \\
\hline Calliphona koenigi Krauss, 1892 & Spain: Canary Islands, Tenerife, Aguamansa, Caldera; $\mathrm{CH} 8066, \mathrm{CH} 8067$ & $28.35^{\circ} \mathrm{N}, 16.483^{\circ} \mathrm{W}$ \\
\hline Tettigonia armeniaca complex & $\begin{array}{l}\text { Turkey: (1) Horasan-Agri, Saclidag Pass, } 2160 \mathrm{~m} \text {; tam1a; } \\
\text { (2) Horasan-Agri, Savsat-Ardahan road, } 1630 \mathrm{~m} \text {; tam2a }\end{array}$ & $\begin{array}{l}39.8747^{\circ} \mathrm{N}, 42.3856^{\circ} \mathrm{E} \\
41.2312^{\circ} \mathrm{N}, 42.4338^{\circ} \mathrm{E}\end{array}$ \\
\hline $\begin{array}{l}\text { Tettigonia balcanica Chobanov } \\
\text { \& Lemonnier-Darcemont, } 2014\end{array}$ & Bulgaria: Pirin Mts, Predela Pass, 1020 m; (one male without ID) & $41.8973^{\circ} \mathrm{N}, 23.3257^{\circ} \mathrm{E}$ \\
\hline Tettigonia cantans (Fuessly, 1775) & Poland: Grębynice near Kraków; tca2a & $50.0957^{\circ} \mathrm{N}, 19.5209^{\circ} \mathrm{E}$ \\
\hline Tettigonia caudata (Charpentier, 1845) & Bulgaria: Byala; tct2 & $43.4717^{\circ} \mathrm{N}, 25.7696^{\circ} \mathrm{E}$ \\
\hline Tettigonia viridissima (Linnaeus, 1758) & $\begin{array}{l}\text { Bulgaria: (1) Haskovo, Perperikon Ruins; tvi5b; } \\
\text { (2) Dobrich, Bolata Bay; tvi5c } \\
\text { Morocco: (1) S Ajabo, } 1360 \mathrm{~m} \text {; tmo1b; } \\
\text { (2) NW Khenifra, } 1100 \mathrm{~m} \text {; tmo2b }\end{array}$ & $\begin{array}{l}41.715^{\circ} \mathrm{N}, 25.4657^{\circ} \mathrm{E} \\
43.3838^{\circ} \mathrm{N}, 28.4715^{\circ} \mathrm{E} \\
33.0659^{\circ} \mathrm{N}, 5.4086^{\circ} \mathrm{W} \\
33.1377^{\circ} \mathrm{N}, 5.9235^{\circ} \mathrm{W} \\
\end{array}$ \\
\hline Tettigonia cf. viridissima & Morocco: S Aïn Zora, 835 m; tmo5e & $34.5708^{\circ} \mathrm{N}, 3.6657^{\circ} \mathrm{W}$ \\
\hline Tettigonia vaucheriana complex & $\begin{array}{l}\text { Morocco: (1) NW Khenifra, } 1100 \mathrm{~m} \text {; tmo2c; } \\
\text { (2) Tilougguite Pass, } 1570 \mathrm{~m} \text {; tmo8a }\end{array}$ & $\begin{array}{l}33.1377^{\circ} \mathrm{N}, 5.9235^{\circ} \mathrm{W} \\
32.0852^{\circ} \mathrm{N}, 6.3003^{\circ} \mathrm{W}\end{array}$ \\
\hline
\end{tabular}



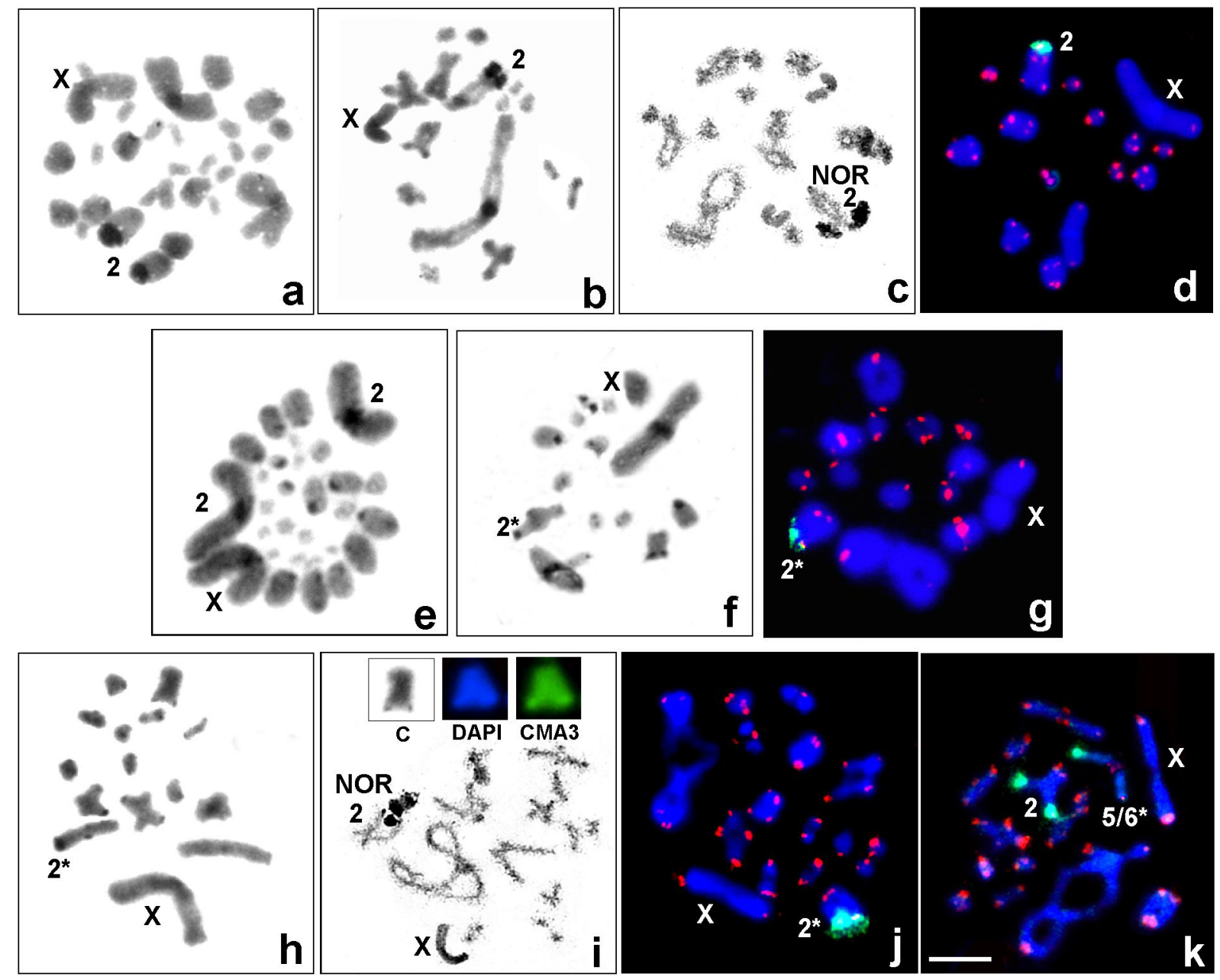

Fig. 2. Examples of chromosome banding in Psalmatophanes barettoi (a-d) and Calliphona koenigi (e-g), and in different species of the genus Tettigonia: T. caudata (h), T. viridissima (i), T. cantans (j) and T. balcanica (k) studied using different techniques. C-banding pattern of spermatogonial metaphases $(a, e)$ and diakinesis $(b, f, h)$; the thick $(a, b)$ and thin $(e, f, h)$ distal $C$-blocks on the second chromosomes/ bivalent in the set. Diakinesis with one active NOR (c, i) and selected C+, DAPI- (blue) and $\mathrm{CMA}_{3}$ (green) bands located in the distal region on the 2nd bivalent (on the top in i). Fluorescence in situ hybridization (FISH) with both 18S rDNA (green) and telomeric DNA (red) probes showing the chromosomal location of rDNA: diakinesis $(\mathrm{d}, \mathrm{g}, \mathrm{j}, \mathrm{k}$ ) with one rDNA sites located on 2nd bivalent, co-localized with NOR (c) and $\mathrm{CMA}_{3}$ (green, i) bands. The second heteromorphic $18 \mathrm{~S}$ rDNA-FISH signal on other medium sized bivalents $(5$ or 6$)$ in T. balcanica (k). Heterochromatin and hybridization areas vary in size between homologous chromosomes (marked by an asterisk in $f, g, h, j, k$ ). $X-s e x$ chromosome. Bar $=10 \mu \mathrm{m}$.

done using the protocol of Warchałowska-Śliwa \& MaryańskaNadachowska (1992). The best chromosome preparations were used for fluorescence in situ hybridization (FISH) with $18 \mathrm{~S}$ ribosomal DNA (rDNA) and telomeric DNA (TTAGG) ${ }_{n}$ probes. FISH was carried out as described previously by Grzywacz et al. (2018). A probe containing a fragment of orthopteran 18S rDNA labelled with biotin-16-dUTP (Roche Diagnostics GmbH, Mannheim, Germany) was used to detect rDNA clusters in metaphase chromosomes. For the detection of telomeric repeats (TTAGG) in metaphase chromosomes, a probe was generated using nontemplate PCR with Tel1 (5' GGT TAG GTT AGG TTA GGT TAG G 3') and Tel2 (5' TAA CCT AAC CTA ACC TAA 3') primers (Grozeva et al., 2011). Visualization of hybridized DNA labelled with biotin or digoxigenin was done using avidin-FITC (Invitrogen, Life Technologies INC., Carlsbad, CA, USA) and anti-digoxigenin rhodamine (Roche Diagnostics $\mathrm{GmbH}$ ), respectively. The chromosomes were counterstained with ProLong Gold antifade reagent containing DAPI (Invitrogen, Life Technologies) under a cover glass. Chromosomes were studied under a Nikon Eclipse 400 microscope.

\section{RESULTS}

All the species analysed (see Table 1) had the same diploid chromosome number with $2 \mathrm{n}=29$ chromosomes and sex determination system X0 (male). We classified autosomes according to size as one long (L) metacentric pair, five medium-sized (M) and eight short (S) acrocentric pairs. The $\mathrm{X}$ chromosome was bi-armed and slightly smaller than the long pair of autosomes (Fig. 2a-k). So, the number of chromosome arms including the $\mathrm{X}$ chromosome (FN) is 32. All individuals had paracentromeric C-bands and in most cases, these heterochromatin blocks were thin and only on the first pair of metacentric chromosomes of Psalmatophanes barettoi and Calliphona koenigi were they thick. In P. barettoi, distally located thick C-bands were located on pair $\mathrm{M}_{2}$, whereas the distal band in other species/specimens on the same bivalent was thin (Fig. 2a, $b, e, f, h)$. 
In order to analyse the distribution of ribosomal and telomeric DNA on the chromosomes in the karyotypes of all taxa, two-colour FISH was used with two differently labelled probes. A similar pattern of chromosomal localization of $18 \mathrm{~S}$ rDNA probes was observed in all taxa, excluding Tettigonia balcanica. Generally, FISH revealed the presence of rDNA only near the distal region of the second pair of chromosomes (Fig. 2d, g, j). Only in T. balcanica was an additional heteromorphic cluster (in term of present/absent) of $18 \mathrm{~S}$ rDNA detected on the distally located region of another medium-sized bivalent $\left(\mathrm{M}_{5}\right.$ or $\mathrm{M}_{6}$ ) (Fig. 2k). The rDNA cluster sometimes varied in size between homologous chromosomes (Fig. 2d, g, j, k). In the taxa studied one (per haploid genome) large cluster of $18 \mathrm{~S}$ rDNA coinciding with a single active NOR was visualized by staining with Ag-NOR and a thin C-band/CMA ${ }_{3}$ positive region was observed (Fig. 2c, i). The telomeric DNA hybridized at the distal ends of all chromosomes. In some bivalents hybridization signals differed in size and intensity between chromosomes of the same taxa, but there was no significant variation between taxa.

\section{DISCUSSION}

Up to now, cytotaxonomic studies on the Glyphonotini have included two species of Glyphonotus, G. thoracicus (Fischer von Waldheim, 1846) and G. coniciplicus Uvarov, 1914 from Kazakhstan $(2 \mathrm{n}=21$; Bugrov, 1990; unpubl. data) and 15 Australian species of the genera Chlorodectes Rentz, 1985; Ectopistidectes Rentz, 1985 and Metaballus Herman, 1974 (2n = 23-27; Ueshima \& Rentz, 1990). In these species, diploid chromosome numbers ranged from 21 to 27 in males and their karyotypes were characterized by the distinct morphology of the chromosomes, which consist of only acrocentric or one to three bi-armed autosomes/sex chromosome. Furthermore, the North American and Australian Tettigoniini genera Capnobotes Scudder, 1897 and Zacycloptera Caudell, 1907 and Nanodectes Rentz, 1985 have 15 to 23 chromosomes of a different morphology (Ueshima \& Rentz, 1979, 1990, 1991). Thus, these species/genera have an evolutionary more advanced karyotype with centric fusions and/or various numbers of tandem fusions and pericentric inversions. However, males of all the species of the genus Tettigonia (i.e. T. cantans, T. caudata, T. viridissima, T. ussuriana Uvarov, 1939 and T. uvarovi Ebner, 1946) throughout the Palaearctic region have a karyotype with 29 chromosomes (WarchałowskaŚliwa, 1984, 1998; Warchałowska-Śliwa \& MaryańskaNadachowska, 1995a; Warchałowska-Śliwa et al., 2002).

Representatives of the genera examined in this study are included in two tribes based on differences in the shape of their cerci and teeth. On the other hand, these genera have the same male karyotype with $2 \mathrm{n}=29$, chromosome morphology and the ancestral X0 sex chromosome determination system. If we assume that most species of the Palaearctic Tettigoniinae are characterized by a basic/ ancestral karyotype with $2 \mathrm{n}=31$ and $\mathrm{FN}=31$ in males (for review see Warchałowska-Śliwa, 1998), the chromosome number of species included in this study could be the result of one Robertsonian translocation (the first autosome pair becomes bi-armed) and a pericentric inversion that modified the ancestral acrocentric $\mathrm{X}$ chromosome into the metacentric $X(F N=32)$. A similar type of translocation is reported in some other species of Tettigoniinae (e.g. Grzywacz et al., 2017a; Warchałowska-Śliwa et al., 2005, 2017). In addition, the present and previous studies indicate that the karyotypes of Tettigonia are stable and there are no changes in the chromosome number and general morphology of the X chromosome in this genus. Currently, an acrocentric $\mathrm{X}$ chromosome is only reported in T. uvarovi (Warchałowska-Śliwa et al., 2002).

Recently the location of ribosomal genes were studied in order to understand genomic differentiation and distinguish between species and evolutionary lines in some bush-crickets of the subfamily Tettigoniinae (Grzywacz et al., 2017a; Warchałowska-Śliwa et al., 2017). One rDNA/ NOR locus (per haploid genome) is coincident with a single active NOR and GC-rich heterochromatin region located near the distal part of the second pair of chromosomes. This appears to be a feature of the typical karyotype of species of Psalmatophanes, Calliphona and Tettigonia. A single bivalent carrying the $18 \mathrm{~S}$ rDNA cluster, but in the interstitial or paracentromeric regions, is reported in other tettigoniids, e.g. in European Platycleidini (Grzywacz et al., 2017a) and Pholidopterini (Warchałowska-Śliwa et al., 2017). Furthermore, one active NOR appears to be a typical feature of karyotypes of European Tettigoniinae (Warchałowska-Śliwa et al., 2005). Only in Tettigonia balcanica (one male analysed, present paper) was there an additional heteromorphic cluster, of $18 \mathrm{~S}$ rDNA detected on a distally located region of another medium-sized bivalent. In addition, some individuals exhibit different intensities of rDNA hybridization on homologous pairs of autosomes. Similar heteromorphism is reported in other bush-crickets and attributed to amplification or loss due to either unequal crossing-over, translocation rearrangements or tandem duplications of ribosomal genes (e.g. Warchałowska-Śliwa et al., 2013). The terminal locations of hybridization signals in Psalmatophanes, Calliphona and Tettigonia indicate that the telomeres are composed of (TTAGG) repeats as in other Orthoptera (e.g. Warchałowska-Śliwa et al., 2011, 2013, 2017; Grzywacz et al., 2014). The number and morphology of chromosomes and marker differentiation did not differ in Psalmatophanes barettoi, Calliphona koenigi and Tettigonia.

The data on morphological characters (Krauss, 1892; Chopard, 1938; Bolívar, 1940, 1991; Holzapfel \& Cantrall, 1972), results of molecular phylogenetic studies (Arnedo et al., 2008) and biogeography/distribution [both genera allo- respectively parapatric to Tettigonia; candidates for an assumed peripatric speciation (see maps for Tettigonia in Grzywacz et al., 2017b; Cigliano et al., 2020)] indicate that Calliphona and Psalmatophanes are probably closely related to Tettigonia. In terms of the number and structure of their chromosomes both genera are similar cytogenetically to Tettigonia, but differ distinctly from Glyphonotus. Based on the cytogenetic information presented and pre- 
vious morphological and molecular evidence, we strongly recommend that Psalmatophanes and Calliphona be transferred from the tribe Glyphonotini to the tribe Tettigoniini.

It should be mentioned that all the species of Glyphonotus (see Miram, 1925) and Calliphona koenigi have infuscated hind wings, which are displayed during defence (Miram, 1925; Pfau \& Pfau, 2002). We consider patterned or coloured hind wings as an analogous trait, also seen e.g., in Capnobotes fuliginosus (Thomas, 1972) (Tettigoniinae) (but not in other species of Capnobotes Scudder, 1897; see Rentz \& Birchim, 1968) and in species of Clonia Stål, 1855 (Saginae) (Kaltenbach, 1990). All these species are large and orthopterans capable of inflicting a severe bite.

The information on the relationships of the tribe Glyphonotini is contradictory. Gorochov (1988) re-established the subfamily Glyphonotinae Tarbinsky, 1932 as a monogeneric group outside Tettigoniinae and close to Conocephalinae. On the other hand, molecular genetic data suggest a close relationship between Glyphonotus (sinensis) and holarctic tettigoniines (Liu Chunxiang, unpubl.). Rentz \& Colless (1990) accepted Gorochov's argument and established the tribe Glyphonotini, but within Tettigoniinae. However, there are technical errors in their disjunctive tribal diagnosis. Rentz \& Colless (1990) give a list of 16 characters of which all Glyphonotini must have at least eight. The first character, number 5 / state 2, is not found in any Glyphonotini according to their data matrix. Character $32 / 6$ is not on the list of the characters (only up to $32 / 3$ ). Based on the characters in the list, the genera under Glyphonotini, Apote Scudder, 1897 and Metaballus Herman, 1884, have only seven and are thus not qualified as Glyphonotini. On the other hand, Tettigonia has also only seven. If after correction this genus also has eight characters, its inclusion would automatically synonymize the tribe in its present definition. The similarity of both genera is underlined by the fact that the type species of Glyphonotus [G. thoracicus (Fischer von Waldheim, 1846)] is described under Locusta, a former name for Tettigonia.

In the first printed version of the Orthoptera Species File (OSF), Otte (1997) adds further species with additional problems: (1) genus Hyphinomos Uvarov, 1921 belongs to the Tettigoniini according to Rentz \& Colless (1990; as Hyphonomos) and Onconotinae according to Sergeev (1995). Otte (1997), however, places it in Glyphonotini without comment. From the characters listed in Rentz \& Colless (1990), Hyphinomos is far from Glyphonotini (has only three of the 16 characters mentioned above). (2) genus $E v$ ergoderes Bolivar, 1936 was not studied by Rentz \& Colless (1990), but Otte (1997) lists it in Glyphonotini without comment.

Mugleston et al. (2018) indicate there are a large number of unsolved problems with the phylogeny of Tettigonioidea. These authors also mention serious problems within the Tettigoniinae, but have neither studied or even mention Glyphonotini. We follow their advice "Tettigoniinae should only include the Holarctic shield back tribes", which indicates that the Holarctic genera may be more closely related to each other than the remaining genera and that currently Glyphonotini should comprise only Glyphonotus, with the remaining four Holarctic genera (Apote, Cyrtophyllicus Hebard, 1908, Evergoderes and Hyphino$m o s$ ) in Tettigoniini sensu lato. The three Australian genera are currently placed in Tettigoniinae without tribal affiliation.

In conclusion, the present study has focused on the cytogenetic mapping of rRNA gene and telomeric sequences, active NOR and general distribution of heterochromatin in different genera/tribes, which is new data on the karyology of the Tettigoniinae. A chromosomal characterization of several species, karyotypic evidence for their relationships and additional support for the identification of species are some of the major contributions that cytogenetics can make to tettigoniid taxonomy. The results of chromosome analyses of Tettigoniinae clearly show the need for a taxonomic revision of this subfamily, whose karyotypic characteristics provide useful and interesting data. Thus, we believe that cytogenetics, morphology and molecular evidence together may resolve the problems with the classification of the groups of Tettigoniinae.

ACKNOWLEDGEMENTS. We would like to thank the collectors of the specimens of Tettigonia and Glyphonotus (D. Chobanov), and Calliphona (M. Heller), and H. López for advice during our (KGH) stay on Tenerife. We also thank A. Hochkirch for the use of his checklist of Orthoptera while in the Canary Islands. Thanks go also to D. Rentz for checking the old data. This research was partly supported by grant 2011/01/B/NZ8/01467 from the National Science Centre, Poland (B. Grzywacz).

\section{REFERENCES}

Arnedo M.A, Oromi P., Martin de Abreu S. \& Ribera C. 2008: Biogeographical and evolutionary patterns in the Macaronesian shield-backed katydid genus Calliphona Krauss, 1892 (Orthoptera: Tettigoniidae) and allies as inferred from phylogenetic analyses of multiple mitochondrial genes. - Syst. Entomol. 33: $145-158$.

Bland R.G. 2001: Additions to the Orthoptera (sens. lat.) of the Canary Islands. - J. Orthopt. Res. 10: 113-119.

Bland R.G., Gangwere S.K. \& Morales Martin M. 1996: An annotated list of the Orthoptera (sens. lat.) of the Canary Islands. - J. Orthopt. Res. 5: 159-173.

Bolívar I. 1940: Sobre los Tetigoninos de las Islas Atlánticas (Orth. Tett.). - Ciencia México 1: 157-159.

Bolívar I. 1991: El genero Calliphona Krauss y sus afines (Orth. Tett.). - Bol. San. Veg. Plagas 17: 361-372.

Bugrov A.G. 1990: Karyotypes of some rare katydids (Orthoptera, Tettigoniidae) from Siberia. In: Redkije Gelminty Kleshchi $i$ Nasekomyje. Nauka, Novosibirsk, pp. 54-60 [in Russian].

Buzzetti F.M., Lecoq M., Fontana P. \& Ode B. 2005: Contribution to the orthopteroid (Insecta: Blattoptera, Orthoptera, Dermaptera) fauna of Sal island (Cape Verde). - Ital. J. Zool. 72: 311-315.

Chopard L. 1938: Les Dermaptères et Orthoptères de Madère. Rev. Fr. Entomol. 4[1937]: 219-229.

Cigliano M.M., Braun H., Eades D.C. \& Otte D. 2020: Orthoptera Species File. Version 5.0/5.0. URL: http://Orthoptera. SpeciesFile.org

De Sousa A.B. \& Borges P.A.V. 2005: Orthoptera. In Borges P.A.V., Cunha R., Gabriel R., Martins A.F., Silva L. \& Vieira V. (eds): A List of the Terrestrial Fauna (Mollusca and Arthropoda) 
and Flora (Bryophyta, Pteridophyta and Spermatophyta) from the Azores. Direccao Regional do Ambiente and Universidade dos Acores, Horta, Angra do Heroismo and Ponta Delgada, p. 188.

Gorochov A.V. 1988: The classification and phylogeny of grasshoppers (Gryllida - Orthoptera, Tettigonoidea). In Pomerenko A. (ed.): Cretaceous Biocoenotic Crisis and the Evolution of Insects. Nauka, Moscow, pp. 145-190 [in Russian].

Grozeva S., Kuznetsova V.G. \& Anokhin B.A. 2011: Karyotypes, male meiosis and comparative FISH mapping of $18 \mathrm{~S}$ ribosomal DNA and telomeric (TTAGG)n repeat in eight species of true bugs (Hemiptera, Heteroptera). - Comp. Cytogenet. 5: $355-374$.

Grzywacz B., Chobanov D.P., Maryańska-Nadachowska A., Karamysheva T.V., Heller K.-G. \& Warchąowska-Śliwa E. 2014: A comparative study of genome organization and inferences for the systematics of two large bushcricket genera of the tribe Barbitistini (Orthoptera: Tettigoniidae: Phaneropterinae). - BMC Evol. Biol. 14: 48, 14 pp.

Grzywacz B., Heller K.-G., Chobanov D.P. \& WarchalowskaŚliwa E. 2017a: Conventional and molecular chromosome study in the European genus Parnassiana Zeuner, 1941 (Orthoptera, Tettigoniinae, Platycleidini). — Folia Biol. (Kraków) 65: $1-8$.

Grzywacz B., Heller K.-G., Warcha£owska-Śliwa E., KaramySheva T.V. \& Chobanov D.P. 2017b: Evolution and systematics of Green Bush-crickets (Orthoptera: Tettigoniidae: Tettigonia) in the Western Palaearctic: testing concordance between molecular, acoustic, and morphological data. - Org. Divers. Evol. 17: 213-228.

Grzywacz B., Tatsua H., Shikata K. \& Warchalowska-Śliwa E. 2018: A comparative chromosome mapping study in Japanese Podismini grasshoppers (Orthoptera: Acrididae: Melanoplinae). - Cytogenet. Genome Res. 154: 37-44.

HARZ K. 1982: Zur Orthopterenfauna (s. lat.) der Kapverdischen Inseln. - Courier Forsch.-Inst. Senckenberg 52: 153-154.

Holzapfel C.M. \& CANTRALl I.J. 1972: Evolution in the Canary Islands. V. The genus Calliphona (Orthoptera: Tettigoniidae). - Occas. Pap. Mus. Zool. Univ. Mich. 663: 1-22.

Kaltenbach A. 1990: The predatory Saginae. In Bailey W.J. \& Rentz D.C.F. (eds): The Tettigoniidae: Biology, Systematics and Evolution. Crawford House Press, Bathurst, pp. 280-302.

KRAUSS H. 1892: Systematisches Verzeichnis der canarischen Dermapteren und Orthopteren mit Diagnosen der neuen Gattungen und Arten. - Zool. Anz. 15: 163-171.

LANGE C.H. 1990: Zur Biogeographie der Heuschrecken (Orthoptera: Saltatoria) von Madeira. - Courier Forsch.-Inst. Senckenberg 129: 109-129.

Mestre J. \& Chiffaud J. 1997: Inventaire et répartition géographique des Acridiens d' Afrique de l' Ouest (Orthoptera, Caelifera). - Bull. Soc. Entomol. Fr. 102: 109-127.

Miram E. 1925: Die Arten der Gattung Glyphonotus Redt. (Orthoptera, Tettigoniidae). - Russk. Entomol. Obozr. (St. Petersburg) 19: 97-104.

Mugleston J.D., Naegle M., Song H. \& Whiting M.F. 2018: A comprehensive phylogeny of Tettigoniidae (Orthoptera: Ensifera) reveals extensive ecomorph convergence and widespread taxonomic incongruence. - Insect System. Div. 2(4): 5, 27 pp.

Отте D. 1997: Orthoptera Species File 7. Tettigonioidea. Orthopterists' Society and the Academy of Natural Sciences of Philadelphia, Philadelphia, 373 pp.

Pfau H.K. \& Pfau B. 2002: Zur Bioakustik und Evolution der Gattung Calliphona (Orthoptera: Tettigoniidae). - Mitt. Schweiz. Entomol. Ges. 75: 253-271.
Rentz D.C.F. \& Birchim J.D. 1968: Revisionary studies in the Nearctic Decticinae. - Mem. Pac. Coast Entomolol. Soc. 3: $1-173$.

Rentz D.C.F. \& ColLess D.H. 1990: A classification of the shieldbacked katydids (Tettigoniinae) of the world. In Bailey W.J. \& Rentz D.C.F. (eds): The Tettigoniidae: Biology, Systematics and Evolution. Crawford House Press, Bathurst \& Springer, Berlin, pp. 352-377.

SchweIzER D. 1976: Reverse fluorescent chromosome banding with chromomycin and DAPI. - Chromosoma 58: 307-324.

Sergeev M.G. 1995: The general distribution of Orthoptera in the eastern parts of the Saharan-Gobian and Scythian subregions. - Acta Zool. Cracov. 38: 213-256.

Sumner S.G. 1972: A simple technique for demonstrating centromere heterochromatin. - Exp. Cell Res. 75: 304-306.

TARBINSKY S.P. 1932: A contribution to our knowledge of the orthopterous insects of USSR. - Bull. Leningrad Inst. Controlling Farm Forest Pests 2: 181-205 [in Russian with some descriptions in English].

Ueshima N. \& Rentz D.C.F. 1979: Chromosome systems in the North American Decticinae with reference to Robertsonian changes (Orthoptera Tettigoniidae). - Cytologia (Tokyo) 44: 693-714.

Ueshima N. \& Rentz D.C.F. 1990: Karyotypes and meiosis of the Australian Tettigoniinae. In Bailey W.J. \& Rentz D.C.F. (eds): The Tettigoniidae. Biology, Systematics and Evolution. Springer, Hong Kong, pp. 303-352.

Ueshima N. \& Rentz D.C.F. 1991: Karyotypes and meiosis of the Australian Tettigoniidae (Orthoptera) II. The genus Nanodectes Rentz (Tettigoniinae). - Invertebr. Taxon. 5: 33-42.

WarchalowSKa-Śliwa E. 1984: Karyological studies on Polish Orthoptera species of the Tettigonioidea superfamily. II. Karyotypes of families Tettigoniidae and Decticidae. - Folia Biol. (Kraków) 32: 311-325.

WARCHALOWSKA-ŚLIWA E. 1998: Karyotype characteristics of katydid orthopterans (Ensifera, Tettigoniidae) and remarks on their evolution at different taxonomic levels. - Folia Biol. (Kraków) 46: 143-176.

WarchalowsKa-Śliwa E. \& Bugrov A.G. 1997: C-banding analysis of embryos of Tettigonia cantans L. (Orthoptera, Tettigoniidae). - Folia Biol. (Kraków) 45: 27-29.

WarchalowsKa-Śliwa E. \& MaryaŃSKa-NadachowSKa A. 1992: Karyotypes, C-bands, NORs location in spermatogenesis of Isophya brevipennis Brunner (Orthoptera: Phaneropteridae). - Caryologia 45: 83-89.

WarChalowSKA-ŚLIWA E. \& MarYaŃSKA-NADACHOWSKA A. 1995a: Cytogenetic studies of the genus Tettigonia (Orthoptera, Tettigonioidea, Tettigoniinae). I. C-bands and NORs activity. Folia Biol. (Kraków) 43: 29-34.

WarchalowsKa-Śliwa E. \& MaryańSKa-NadachowsKa A. 1995b: Cytogenetic studies of the genus Tettigonia (Orthoptera, Tettigonioidea, Tettigoniinae). II. Heteromorphism of C-bands. - Folia Biol. (Kraków) 43: 99-106.

WarchalowsKa-Śliwa E., Kostia D. \& Śliwa L. 2002: Cytological and morphological differences between two species of the genus Tettigonia (Orthoptera, Tettigoniidae) from Korea. Folia Biol. (Kraków) 50: 23-28.

WarchalowsKa-Śliwa E., Heller K.-G. \& MaryańsKaNADACHOWSKA A. 2005: Cytogenetic variability of European Tettigoniinae (Orthoptera, Tettigoniidae): Karyotypes, C-and Ag-NOR-banding. - Folia Biol. (Kraków) 53: 161-171.

WarchalowsKa-Śliwa E., MaryańSKa-NadachowsKa A., Grzywacz B., Karamysheva T., Lehmann A.W., Lehmann G.U.C. \& Heller K.-G. 2011: Changes in the numbers of chromo- 
somes and sex determination system in bushcrickets of the genus Odontura (Orthoptera, Tettigoniidae, Phaneropterinae). - Eur. J. Entomol. 108: 183-195.

WarchałowsKa-Śliwa E., Grzywacz B., MaryańsKa-Nadachowska A., Karamysheva T., Chobanov D.P. \& Heller K.-G. 2013: Cytogenetic variability among Bradyporinae species (Orthoptera: Tettigoniidae). — Eur. J. Entomol. 110: 1-12.
Warchalowska-Śliwa E., Grzywacz B., Heller K.-G. \& ChoBANOV D.P. 2017: Comparative analysis of chromosomes in the Palaearctic bush-crickets of tribe Pholidopterini (Orthoptera, Tettigoniinae). - Comp. Cytogen. 11: 309-324.

Received February 3, 2020; revised and accepted March 26, 2020 Published online April 17, 2020 